\title{
GENDER EQUITY AND REDUCTION OF POST-HARVEST LOSSES IN AGRICULTURAL VALUE CHAINS
}

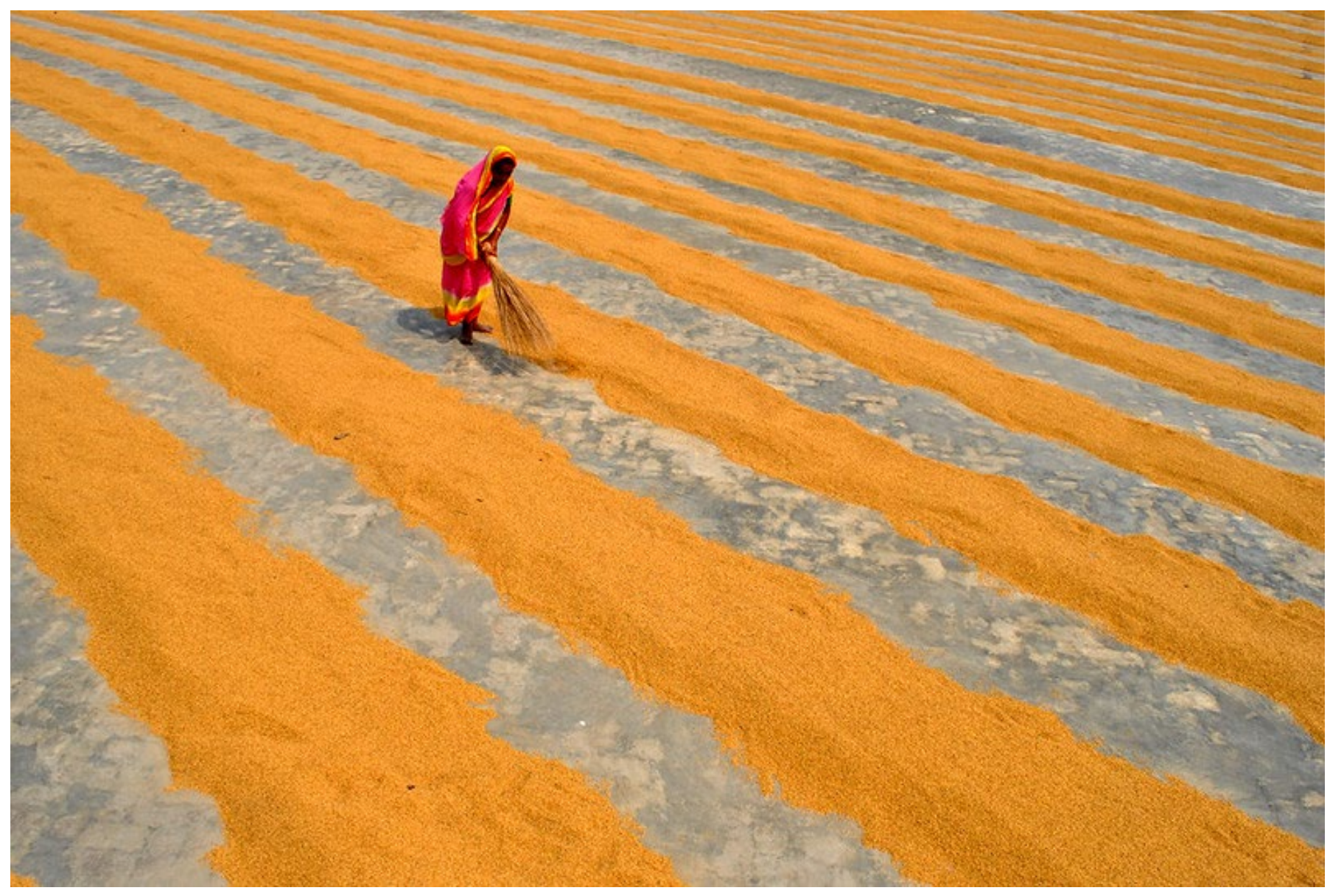

GAIN Working Paper n²0

April, 2021

Stella Nordhagen

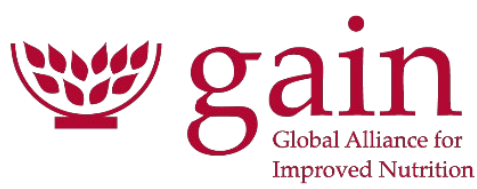




\section{ABOUT GAIN}

The Global Alliance for Improved Nutrition (GAIN) is a Swiss-based foundation launched the UN in 2002 to tackle the human suffering caused by malnutrition. Working with governments, businesses and civil society, we aim to transform food systems so that they deliver more nutritious food for all people, especially the most vulnerable.

\section{Recommended citation}

Nordhagen, S. Gender equity and reduction of post-harvest losses in agricultural value chains. Global Alliance for Improved Nutrition Working Paper \#20. Geneva, Switzerland, 2021. DOI: https://doi.org/10.36072/wp.20

\section{(c) The Global Alliance for Improved Nutrition (GAIN)}

This work is available under the Creative Commons Attribution-Non-Commercial-Share Alike 4.0 IGO licence (CC BY-NC-SA 4.0 IGO; https://creativecommons.org/licenses/by-nc-sa/4.0/). Under the terms of this licence, you may copy, redistribute and adapt the work for non-commercial purposes, provided the work is appropriately cited, as indicated below. In any use of this work, there should be no suggestion that GAIN endorses any specific organisation, products or services. The use of the GAIN logo is not permitted. If you adapt the work, then you must license your work under the same or equivalent Creative Commons license. The contribution of third parties do not necessarily represent the view or opinion of GAIN.

\section{Acknowledgements}

Saul Morris and Teale Yalch provided useful feedback on earlier drafts of this paper. The author also thanks the staff of the GAIN Post-harvest Loss Alliance for Nutrition programme, Zerihun Zena and Rahmi Kasri, for their participation in a programme review on which this paper draws. All photographs included in this document have been taken with consent for use in publications.

\section{GAIN WORKING PAPER SERIES}

The GAIN Working Paper Series provides informative updates on programme approaches and evaluations, research, and other topics relevant to helping reshape the food system to improve the consumption of nutritious, safe food for all people, especially the most vulnerable.

The Global Alliance for Improved Nutrition (GAIN)

Rue de Varembé 7

1202 Geneva

Switzerland

T: +41227491850

E: info@gainhealth.org

www.gainhealth.org 


\section{SUMMARY}

High levels of food loss help drive low availability and affordability of nutrient-dense foods such as fresh fruit and vegetables-which, in turn, contribute to poor-quality diets and poor nutrition outcomes in many low- and middle-income countries. Much of this loss occurs at the post-harvest stage, in which women often play a large role, and gender relations shape decisions along agricultural value chains, including adoption and use of technologies that could reduce post-harvest loss. However, there has been limited examination of how gender and gender-equity issues might impact post-harvest loss. As such, this working paper reviews the literature to draw together these two important topics.

The paper first summarises the important role that women play in the post-harvest stage and notes various reasons why they might face different (likely higher) loss rates than men. It then explores barriers women face to the adoption of post-harvest loss-reduction technologies and some of the unintended consequences these technologies may have for women and gender relations. It highlights important data gaps on the topic of gender and post-harvest loss before discussing ways in which gender and gender equity can be better taken into account in programming related to post-harvest loss reduction.

\section{KEY MESSAGES}

- Women play an outsized role in the post-harvest handling and processing stage of the value chain, where considerable food loss occurs.

- Due to lower access to resources and information, women may be at higher risk of experiencing high post-harvest loss rates and have lower ability to adopt lossreduction technologies.

- These dynamics appear to be highly context specific, and the limited data and research available on gender and post-harvest loss make it difficult to diagnose challenges and identify solutions.

- Post-harvest loss interventions should be designed based on an understanding of the local gender context, in partnership with women, and with an eye to increasing their empowerment. 


\section{BACKGROUND AND OBJECTIVE}

Nutrition contributes to improved health, development, productivity, and wellbeing, placing it at the foundation of achieving many of the Sustainable Development Goals (SDGs) (1) —and central within SDG 2, which aims at ending hunger and all forms of malnutrition. However, about one quarter of the population suffers from food insecurity, $70 \%$ of children in subSaharan Africa and South Asia do not consume a diet of minimum diversity, and about $46 \%$ of them are deficient in Vitamin A $(2,3)$. At present, vegetable intake is below recommended levels in $88 \%$ of countries (4). Diets low in fruits, nuts and seeds, or vegetables are among the main dietary risks that contribute to the global burden of disease, and it is estimated that improving dietary quality could prevent more than 11 million premature deaths, about $24 \%$ of total deaths in 2017 (5).

Among the causes of these low levels of consumption are low food availability and high prices, particularly for nutrient-dense foods like vegetables, fruit, meat, fish, and dairy: in most countries, current levels of vegetable supply are insufficient to meet recommendations (4). Sub-Saharan Africa, for example, has about half the per capita vegetable availability of North America, a level that has barely grown in the past 50 years (6). On top of this lack of supply are prices that are too high relative to consumers' purchasing power: it is estimated that 3 billion people cannot currently afford a healthy diet (7).

In turn, one driver of low availability and affordability is high levels of food loss: at present, an estimated one-third of food produced is lost or wasted before being consumed (8), and the amount of food estimated as lost in 2017 would be enough to feed 940 million people (9). Food loss can increase food prices, reduce food availability and desirability, and reduce nutrient content. It is estimated that reducing food loss and waste in low- and middle-income countries (LMICs) by $10 \%$ could reduce fruit and vegetable prices by $14 \%$ (10). Reducing loss and waste thus has the potential to reduce hunger and undernutrition (12) while improving the environmental sustainability of the food system (11). The importance of addressing food loss and waste has been recognised in SDG 12, which aims to ensure sustainable consumption and production patterns-including by halving the level of food waste (11).

Equally central to achieving the SDGs is gender equality (SDG 5). Gender equality also underpins the achievement of multiple other SDGs_including SDG 2, as women's empowerment and gender equity are key determinants of access to nutritious food and productive resources. With some heterogeneity (12), there is generally a positive association between women's empowerment and their own nutrition and food security and that of their young children (13-15), with studies linking maternal decision-making (16-19), autonomy $(20,21)$, and empowerment in agricultural production (22) to indicators of better child or women's nutrition. At present, however, women and girls are disproportionately denied access to education and healthcare, suffer from violence and discrimination, lack access to decent work, and face gender wage gaps_as well as being under-represented in political decision-making (11).

This working paper will argue that these three issues—nutrition, gender equity, and food loss and waste, though rarely seen as interconnected, overlap: gender must be taken into account in interventions to reduce food loss, particularly if such efforts aim to benefit nutrition. Based 
on a non-systematic narrative review of research and implementation experience, this paper discusses why gender is a relevant consideration in attempts to address post-harvest food loss and discusses potential ways to make loss-reduction interventions more gendersensitive. First, we summarise the main features of current post-harvest food loss and technologies to address it.

\section{POST-HARVEST FOOD LOSS}

Loss and waste occur at every point of the food supply chain, from farm to fork: during production, through storage and distribution, and in retail outlets and consumers' homes. In higher-income countries, much of this loss occurs at the retail and consumer levels (e.g., when expired or cosmetically damaged food is thrown out). In LMICs, however, much of it happens before this stage: it is estimated that $14 \%$ of all food produced globally is lost after harvest and before retail (23). For perishable (and highly nutrient-dense foods), the levels are even higher, exceeding $20 \%$ for fruits and vegetables (23). In areas with poorly developed supply chains and limited infrastructure (such as roads and electricity grids), levels are higher still, reaching an estimated $43.5 \%$ for vegetables and $55.9 \%$ for fruits in sub-Saharan Africa (24). For the purposes of this paper, we focus on this post-harvest loss (PHL), given its significant scale in LMIC food systems.

Numerous technologies and techniques exist for reducing PHL levels. These include simple solutions, such as reusable plastic crates for storing and transporting fresh fruit and vegetables, which can significantly lower levels of loss-for example, from $40 \%$ to $5 \%$ in studies in Nigeria $(25,26)$ and from $15-20 \%$ to $4-5 \%$ in research in India $(27)$. They also include those that are more technologically complex, such as hermetic storage bags, processing technologies, or refrigerated trucks and cold-storage rooms. It has been estimated that scaling-up promising interventions could reduce losses of vegetables and fruits in subSaharan Africa to $10.7 \%$ and $24.8 \%$, respectively (24).

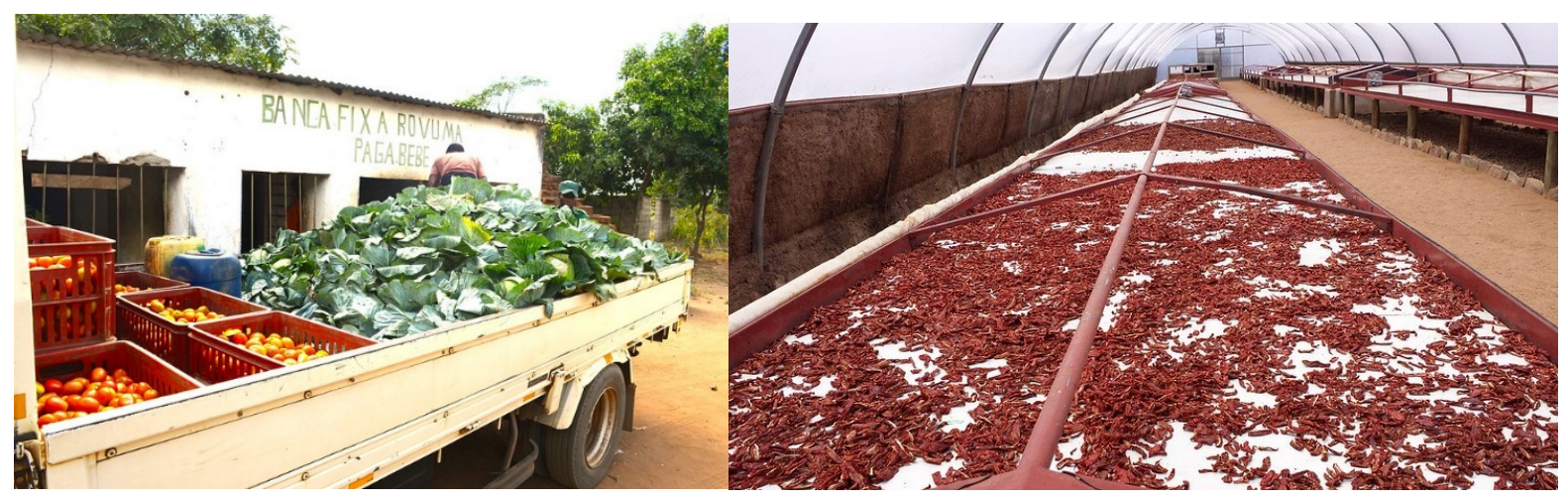

Figure 1. Reusable Plastic Crates (left) and solar tunnel dryers (right) are two examples of technologies to reduce PHL

Since loss occurs throughout the value chain, achieving a major reduction in loss levels would require such technologies to be adopted, where relevant, throughout the value chain-e.g., in the warehousing, cold storage, logistical, wholesale, processing, and retail services that link farms to consumers (28). The decision to deploy these potentially impactful interventions, however, is generally made by individual farmers, entrepreneurs, or business owners within a 
supply chain. As such, it is important to consider these actors' needs, preferences, and constraints, as well as the relationships between them. These actors comprise both men and women, interacting with one another and embedded within larger social structures that are not necessarily gender neutral—making gender issues relevant to consider.

\section{WHAT DOES GENDER HAVE TO DO WITH POST-HARVEST LOSS?}

\section{WOMEN ARE HIGHLY INVOLVED IN POST-HARVEST STAGES OF FOOD VALUE}

\section{CHAINS}

Women's participation in agriculture varies by region (29), but in many African countries, women make up close to $50 \%$ of the agricultural labour force (30). Women are also active across the latter stages of food value chains, from on-farm processing to retail. Indeed, compared to other sectors, women tend to be over-represented in the agri-food sector. In West Africa, for example, $68 \%$ of employed women work in the food system, and women represent $83 \%$ and $72 \%$ of those employed in food processing and food marketing, respectively (31). While women tend to be underrepresented in wholesale and formal-sector retail (e.g., supermarkets) (32,33), they are often dominant in informal-sector retail-for example, about $80-90 \%$ of street food sellers in Nigeria are women $(34,35)$. Upstream in the value chain, women tend to be concentrated in post-harvest handling and processing $(32,33)$. In many LMIC settings post-harvest operations such as processing, handling, and storage are principally carried out by women (36). Gender relations are central to the social and economic context that shapes agricultural value chains, including the types of jobs available to men and women, pay gaps, time use, decision-making, and access to labour-saving technology (37), and the high level of women's involvement in the post-harvest stage confirms the relevance of considering gender when examining post-harvest loss.

\section{GENDER LIKELY IMPACTS POST-HARVEST LOSS}

Women's typically lower endowment of resources represents one way in which gender may influence PHL levels in LMICs. PHL levels are influenced by access to technology, market information, knowledge and training, transport, and infrastructure (23). All of these factors are also influenced by gender, with women in LMICs (particularly in rural areas) generally having lower access than men (38-41). For example, contact with extension agents is lower among women farmers (42), giving them less access to the information and skills training that facilitate the adoption of new technologies (including those for loss reduction during storage and transport). Indeed, African women farmers are less likely than their male counterparts to adopt improved agricultural technologies (43). Research on grain loss in rural Ethiopia (44) found that women's disempowerment led them to use less effective methods to prevent losses, some of which (e.g., treating grain with chemicals) might threaten food safety.

Women's ownership of land also typically lags far behind that of men (29), which may make them less willing or able to invest in PHL-prevention equipment or practices. Women are often less involved than men in cooperatives and other professional networks; this can further limit access to processing facilities, technologies, and markets, exacerbating PHL (23). It can also limit access to knowledge and social capital, which facilitate technology adoption. Women also generally have lower access to high-quality storage facilities and technologies, which can result in more damage and loss (32). This lack of access can pressure women to sell 
their crops during harvest season, when prices are at their lowest, exacerbating income gaps between men and women (32). Finally, gender differences in crop choice can influence PHL; in many settings, women are concentrated in the more perishable crop value chains (e.g., fresh vegetables, as opposed to nuts and grains); this can increase their need for suitable storage options and their losses when they lack them (32).

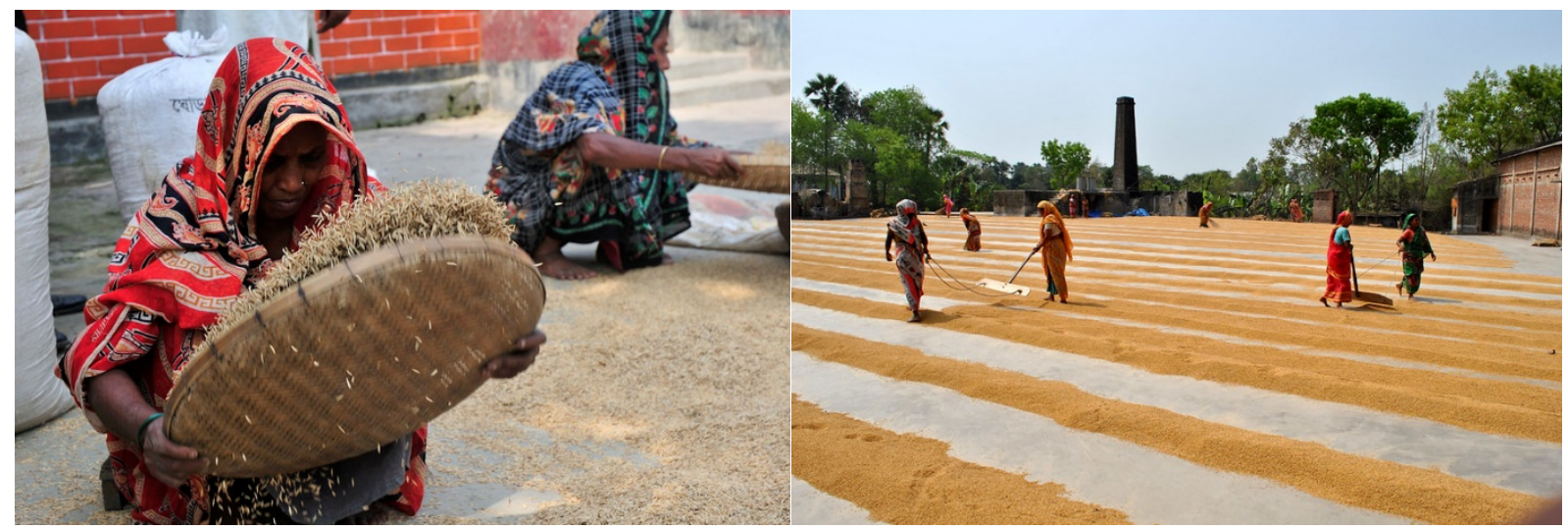

Figure 2. Women often play large roles in the post-harvest stage of the value chain, such as winnowing (left) and drying grain (right)

\section{GENDER ALSO IMPACTS THE ADOPTION OF PHL-REDUCTION TECHNOLOGIES}

Women also face constraints when adopting PHL-reduction technologies. Women may have different preferences for PHL-reduction technologies than men $(45,46)$, but the technology design process often does not include the voices of women or prioritises those of men. Within a household, men and women often have different levels of bargaining power when making decisions, as well as different preferences for allocating resources (47-49). These dynamics have potential implications for technology adoption. A study on PHL reduction for cassava in Ghana, Nigeria, and Vietnam, for example, found that men made the final decisions to allocate and use resources related to $\mathrm{PHL}$ reduction and owned most production and processing assets - although women were commonly responsible for post-harvest management (50). Gender inequalities in time use, decision-making, and access to technology were also identified as drivers of PHL for maize, millet and sorghum in Burkina Faso (51). Research in Zambia found that women also had lower access to fish processing technologies, increasing their loss rates $(52,53)$.

Women's limited access to assets and financing $(54,55)$ may also make them less able to adopt PHL-reduction technologies (32). This applies to not only smallholder farmers but also women-owned businesses at other stages of the supply chain: women entrepreneurs in LMICs tend to face barriers to establishing, formalising, and growing agri-food businesses (56) — which may impact those businesses' ability to adopt loss-reduction technologies and practices. Barriers to accessing business finance tend to be particularly high for agri-food firms in LMICs, given the perceived riskiness of the sector (57).

A study of the fish supply chain in Zambia $(52,53)$ casts light on how women's double work burdens (i.e., carrying out childcare and other household tasks at the same time as 'productive' work) may impact PHL. Double-tasking in this way was found to lead to less attention paid to processing, resulting in over-processing or loss/theft during drying. Some 
women also often started out with lower-quality fish to process, as they could not carry heavy loads or travel long distances due to domestic responsibilities, making it not possible to access fresher, better-quality fish found in more distant places. This resulted in higher losses for women processors.

Finally, when technology is adopted, it can have unexpected effects on women (both positive and negative) due to gender roles and dynamics. A gender analysis of improved storage silos for maize in Zambia found that switching from traditional granaries to metal silos improved food security in some households but led to women losing their traditional role of controlling household maize stocks in others-and also led to job creation for silo-makers, all of whom were men (58). However, women in Kenya reported that the use of silos reduced their labour burdens and improved their health (due to lower levels of storage chemical exposure) (59). And promoting silos and hermetic bags for maize storage in Zimbabwe was found to slightly increase sharing of post-harvest tasks between men and women, to increase shared decisionmaking, and to decrease women's time use for maize cleaning (due to lower levels of contamination) (60). In Tanzania, research found that warehousing systems that were meant to improve quality of rice storage was disempowering for women, as only the person who deposited the crops in the warehouse (typically the husband) was given information about their rice stock (46).

\section{IMPORTANT GENDER DATA GAPS EXIST RELATED TO POST-HARVEST LOSS}

Despite these myriad linkages, there has generally been limited investment into understanding and addressing gender-equity issues at the post-harvest stage than within agricultural production (32). In particular, gender has rarely been considered in research on $\mathrm{PHL}$, and most estimates of PHL levels do not report separately for male and female farmers or value chain actors; for example, a recent systematic review of PHL in Africa found that only 3 of 213 studies reported loss rates separately for men and women (24). The evidence that does exist is inconsistent. A study of the fish supply chain in Zambia $(52,53)$ found that selfreported losses were higher for female than male processors and traders. In contrast, analysis of survey data from Tanzania found women-headed households to have lower PHL likelihood than those headed by men (61)_but differences between men and women within households were not taken into account.

As these contrasting results emphasise, different dynamics and interactions between gender and PHL noted above are highly context-specific-making it particularly important to obtain more and better data these differences across contexts.

\section{TAKING GENDER INTO ACCOUNT IN POST-HARVEST LOSS-REDUCTION PROGRAMMING}

There are thus numerous ways in which gender can influence PHL levels and the ability to address it. Given this, gender issues should be considered in the design and implementation of PHL-reduction programmes. In its 2019 State of Food and Agriculture report, FAO emphasised the importance of gender-sensitive approaches to food loss reduction, stating, 'interventions to improve women's standing and decision-making power in the consumption and sale of household production may help reduce food losses' ((23), p. 79). There are 
demonstrated links between women's empowerment and nutrition and food security, and agricultural interventions to improve nutrition tend to be more impactful when taking women's empowerment into account (62). As such, enhancing women's ability to access and benefit from PHL approaches and technologies could have dividends not only for reducing $\mathrm{PHL}$ levels but also for improving household nutrition.

Interventions that reduce PHL could be empowering if they reduce women's workloads and drudgery and free their time to engage in other income-generating or wellbeing-enhancing activities. Alternatively, technology introduction can displace women from their traditional roles (e.g., winnowing or grinding grain) (63), and could place additional burdens on women's time. As many women already have limited time to begin with-often juggling productive work with care work and community service-this can have potentially detrimental consequences for their empowerment and wellbeing (64). It can even impact nutrition and health by reducing time for cooking, childcare, accessing healthcare, and leisure (65-69), with specific impacts varying by context (70). It is thus important to consider whose labour is being saved by 'labour-saving technologies' related to $\mathrm{PHL}$, and at what point in the value chain (60). And PHL reduction intervention can also have unexpected and mixed effects — such as displacing women's traditional role and lessening their control but still having a net positive effect due to significantly reducing drudgery (71).

This makes it critical to carefully consider women's needs and preferences, within a given context, in the design of PHL technologies and loss-reduction interventions. Women should be part of the design process for new technologies; in settings where girls play a large role in post-harvest handling, their needs and preferences should also be considered.

Recommendations for PHL-reduction approaches should be based on gender-sensitive analyses that identify any gender-based constraints that actors face at critical loss points in the supply chain and consider differences in needs, capacities, and preferences between women and men. For example, such technologies and techniques could include storage equipment that requires little financial outlay and is adaptable to smaller scales of production as well as processing approaches that extend shelf life (thereby avoiding food loss) while also resulting in higher-value or faster-cooking nutritious foods-thereby facilitating women's ability to earn income or to conveniently feed their families. However, while being responsive to the needs of women and girls, it is important to avoid pigeon-holing women into a particular 'type' of consumer or producer (e.g., low-growth or small scale), as this can feed negative stereotypes and be counter-productive in the long run (72). 
Gender issues also need to be taken into account when considering the means through which an intervention is distributed. For example, GAIN's Post-harvest Loss Alliance for Nutrition (PLAN) programme (see Box 1) worked to distribute reusable plastic crates through tomato farmers' cooperatives and traders' associations in Ethiopia-a seemingly genderneutral intervention. However, the approach was found to have poor reach among women, as almost all members of these organisations were men (73). Training approaches that require women to travel or spend extensive time outside the home may run into barriers related to women's constrained time, limited transport options, and gender norms. Technology diffusion approaches that rely on private-sector financing for the purchase of technologies are likely to also be gender-inequitable, as women-owned agri-food businesses in LMICs often face higher barriers to accessing financing (57).

To improve gender equity, potential approaches to consider are working with existing women's groups, using women as trainers or extensionists, using gender targets or incentives to increase women's representation and leadership within male-dominated groups, and focusing on the parts of the value chain where women tend to be most active (e.g., processing as opposed to transport). If feasible, adopting gender-transformative approaches that integrate interactive behaviour change communication on gender equity for decisionmaking and resource use may help to shift underlying gender norms and better empower women, such as by increasing their decision-making power on topics related to $\mathrm{PHL}$ reduction (74). Across all intervention types, it will be essential to include women as active participants in shaping the modalities of service delivery to ensure that it responds to their

\section{BOX 1. GAIN'S POSTHARVEST LOSS ALLIANCE FOR NUTRITION (PLAN)}

Aiming to support agri-food supply chain SMEs to reduce postharvest loss, GAIN created the Postharvest Loss Alliance for Nutrition (PLAN) in 2015. PLAN brings together different actors from across a given supply chain within a given setting to jointly identify the causes of PHL and work to address them, with a specific focus on the availability of highly nutritious foods. PLAN targets three main challenges: a lack of coordination among supply chain actors; a lack of access to the technical expertise needed to adopt improved technologies or support new innovations, particularly cold chain, crating, and processing; and insufficient access to the financial resources needed to adopt improved methods and technologies. PLAN does this through three main interventions: (1) Improving coordination among actors within a given food supply chain through the Alliance; (2) Building capacity, providing access to finance, and encouraging SMEs to adopt improved practices and technologies through business-tobusiness (B2B) mentorship; and (3) Fostering new innovations in post-harvest loss technology through Innovation Challenges. To date, PLAN has been implemented in Nigeria and Ethiopia (with a focus on tomatoes) and Indonesia (with a focus on fish) (65). 
needs and to carefully consider the gender dynamics shaping the value chain (54) and where $\mathrm{PHL}$ fits within those.

Finally, the gaps women face in access to training, skills, and technology are due to a combination of gender norms and social biases, lower capital access, mobility limitations, lower levels of education, lack of decision-making power, and limited time due to women's high burden of care work $(39,75)$. The benefits of women's participation in agricultural value chains are largely determined by their control of productive resources and household level decisions (76), and attempts to increase women's entrepreneurship often have limited benefits if restricted to small, household-based enterprises that do not provide access to more lucrative revenue streams (77). PHL-reduction interventions must take such factors into account when considering their approach-and, in the long term, work to transform social and political systems to create a more level playing field for men and women farmers and entrepreneurs in the agri-food sector. Through such approaches, PHL-reduction programmes can not only reach women, but also better benefit and empower them (78).

\section{CONCLUSION}

This brief review has highlighted certain gender issues associated with post-harvest loss and interventions to reduce it in LMICs. There are some limitations to this analysis: it tended to focus primarily on challenges and barriers, largely due to the focus on those in prior research, but it is important to note that there are also advantages to being a female farmer and entrepreneur and that women often take more nuanced views of how gender impacts their livelihood, seeing both advantages and downsides (79). Further, many barriers to reducing $\mathrm{PHL}$ in LMICs are faced by both men and women-even if some may be higher for women than men. Women are also not a homogenous group, and gender is only one component of identity; the opportunities and constraints women face when it comes to PHL reduction thus vary widely (such as across ethnic groups, (59)), with many exceptions to the general tendencies discussed here. Finally, very limited research has been done on gender issues related to $\mathrm{PHL}$, and the results that have been found have proven highly context-specific: there is a need for more in-depth and rigorous work examining different technologies and approaches in diverse value chains and geographies and among diverse men and women.

Despite these limitations, the review confirmed that post-harvest loss is not a gender-neutral phenomenon. Instead, gender likely influences PHL levels as well as a farmer or entrepreneur's ability to adopt PHL-reducing technologies. This occurs due to different roles within the value chain and sector, differences in decision-making power, different preferences, and differences in access to information, financing, and technology-as well as to technology development and programme implementation that does not consider the needs of both women and men. Women's ability to reduce loss may also be impacted by their 'dual burden' of care work alongside 'productive' work.

Improving the uptake and effectiveness of PHL-reduction strategies will likely depend partly on ensuring that the voices of women-who represent a large share of the actors in agri-food value chains-are taken into account in the design of interventions and approaches for implementing them. Through a women-led or women-centred approach, and through pairing $\mathrm{PHL}$-focused interventions with those aiming for women's empowerment, considerable 
progress could be made to reducing levels of post-harvest loss, with positive ramifications for environmental sustainability and human nutrition. 


\section{REFERENCES}

1. Development Initiatives. Global Nutrition Report 2017: Nourishing the SDGs. Bristol: Development Initiatives; 2017.

2. Global Alliance for Improved Nutrition (GAIN), Johns Hopkins University. The Food Systems Dashboard [Internet]. Global Alliance for Improved Nutrition (GAIN) and Johns Hopkins University; 2020 Jun [cited 2020 Sep 24]. Available from: https://foodsystemsdashboard.org/

3. Stevens GA, Bennett JE, Hennocq Q, Lu Y, De-Regil LM, Rogers L, et al. Trends and mortality effects of vitamin A deficiency in children in 138 low-income and middle-income countries between 1991 and 2013: a pooled analysis of population-based surveys. The Lancet Global Health. 2015 Sep;3(9):e528-36.

4. Kalmpourtzidou A, Eilander A, Talsma EF. Global Vegetable Intake and Supply Compared to Recommendations: A Systematic Review. Nutrients. 2020 May $27 ; 12(6): 1558$

5. Wang DD, Li Y, Afshin A, Springmann M, Mozaffarian D, Stampfer MJ, et al. Global Improvement in Dietary Quality Could Lead to Substantial Reduction in Premature Death. The Journal of Nutrition. 2019 May 2;149(6):1065-74.

6. GAIN and Johns Hopkins. Food Systems Dashboard [Internet]. Available from: https://foodsystemsdashboard.org

7. FAO, IFAD, UNICEF, WFP and WHO. The State of Food Security and Nutrition in the World 2020 [Internet]. FAO, IFAD, UNICEF, WFP and WHO; 2020 [cited 2021 Jan 23]. Available from: http://www.fao.org/documents/card/en/c/ca9692en

8. FAO. Global food losses and food waste - Extent, causes and prevention. Rome: Food and Agriculture Organization; 2011.

9. Abbade EB. Estimating the nutritional loss and the feeding potential derived from food losses worldwide. World Development. 2020 Oct;134:105038.

10. Gustavsson J, Cederberg C, Sonesson U. Global food losses and food waste: extent, causes and prevention; study conducted for the International Congress Save Food! at Interpack 2011, [16 - 17 May], Düsseldorf, Germany. Rome: Food and Agriculture Organisation of the United Nations; 2011. 29 p.

11. United Nations Development Programme. Sustainable Development Goals. [Internet]. 2020. Available from: https://www.undp.org/content/undp/en/home/sustainabledevelopment-goals.html

12. Harris-Fry H, Nur H, Shankar B, Zanello G, Srinivasan C, Kadiyala S. The impact of gender equity in agriculture on nutritional status, diets, and household food security: a mixedmethods systematic review. BMJ Global Health. 2020 Mar 1;5(3):e002173.

13. Bhagowalia P, Menon P, Quisumbing AR, Soundararajan V. What Dimensions of Women' $s$ Empowerment Matter Most for Child Nutrition? Evidence Using Nationally Representative Data from Bangladesh. Washington, DC: International Food Policy Research Institute (IFPRI); 2012. Report No.: Discussion Paper \#01192. 
14. Guha-Khasnobis B, Hazarika G. Women's status and children's food security in Pakistan. Helsinki, Finland: World Institute for Development Economics (UNU-WIDER); 2006. (WIDER Discussion Papers). Report No.: 2006/03.

15. Fafchamps M, Kebede B, Quisumbing AR. Intrahousehold Welfare in Rural Ethiopia. Oxford Bulletin of Economics and Statistics. 2009 Aug;71(4):567-99.

16. Shroff MR, Griffiths PL, Suchindran C, Nagalla B, Vazir S, Bentley ME. Does maternal autonomy influence feeding practices and infant growth in rural India? Social Science \& Medicine. 2011 Aug;73(3):447-55.

17. Hindin MJ. Women's power and anthropometric status in Zimbabwe. Social Science \& Medicine. 2000 Nov;51(10):1517-28.

18. Chakraborty P, Anderson AK. Maternal Autonomy and Low Birth Weight in India. Journal of Women's Health. 2011 Sep;20(9):1373-82.

19. Sethuraman K, Lansdown R, Sullivan K. Women's Empowerment and Domestic Violence: The Role of Sociocultural Determinants in Maternal and Child Undernutrition in Tribal and Rural Communities in South India. Food Nutr Bull. 2006 Jun;27(2):128-43.

20. Brunson EK, Shell-Duncan B, Steele M. Women's autonomy and its relationship to children's nutrition among the Rendille of northern Kenya. Am J Hum Biol. 2009 Jan;21(1):55-64.

21. Carlson GJ, Kordas K, Murray-Kolb LE. Associations between women's autonomy and child nutritional status: a review of the literature. Maternal \& Child Nutrition. 2015 Oct $1 ; 11(4): 452-82$.

22. Malapit HJL, Quisumbing AR. What dimensions of women's empowerment in agriculture matter for nutrition in Ghana? Food Policy. 2015 Apr;52:54-63.

23. FAO. The State of Food and Agriculture 2019. Moving forward on food loss and waste reduction. Rome: Food and Agriculture Organization of the United Nations; 2019.

24. Affognon $H$, Mutungi $C$, Sanginga $P$, Borgemeister $C$. Unpacking Postharvest Losses in Sub-Saharan Africa: A Meta-Analysis. World Development. 2015 Feb;66:49-68.

25. Kok MG, Groot JJ, Dastoum S, Plaisier C, Dijkxhoorn Y, Wagenberg CPA van. A Measurement tool on Food losses and Waste: Applied in a tomato value chain in Nigeria. Wageningen: Wageningen University \& Research; 2019.

26. Benson OB, Ambee IA, Osegbo AN, Okonkwo EU. Re-useable plastic crates as a veritable tool for handling of fresh fruits and vegetables: Lagos State as a case study. Journal of Stored Products and Postharvest Research. 2020;11(1).

27. World Economic Forum. Enabling Trade: From Valuation to Action [Internet]. Geneva, Switzerland: World Economic Forum; 2014 Jan. Available from: http://www3.weforum.org/docs/WEF_EnablingTradeReport_2014.pdf

28. AGRA. The Hidden Middle: A Quiet Revolution in the Private Sector Driving Agricultural Transformation. (AGRA African Agriculture Status Report 2018). [Internet]. Alliance for a Green Revolution for Africa (AGRA); 2019. Available from: https://agra.org/wpcontent/uploads/2019/09/AASR2019-The-Hidden-Middleweb.pdf 
29. Doss C, Meinzen-Dick R, Quisumbing A, Theis S. Women in agriculture: Four myths. Global Food Security. 2018 Mar;16:69-74.

30. Palacios-Lopez A, Christiaensen L, Kilic T. How much of the labor in African agriculture is provided by women? Food Policy. 2017 Feb;67:52-63.

31. Allen T, Heinrigs $P$, Heo I. Agriculture, Food and Jobs in West Africa [Internet]. Paris: OECD; 2018. (West African Papers). Report No.: 14. Available from: https://www.oecdilibrary.org/content/paper/dc152bc0-en

32. IFC. Investing in Women along Agribusiness Value Chains. Washington, DC: International Finance Corporation (IFC); 2016.

33. Masamha B, Thebe V, Uzokwe VNE. Mapping cassava food value chains in Tanzania's smallholder farming sector: The implications of intra-household gender dynamics. Journal of Rural Studies. 2018 Feb;58:82-92.

34. Aluko OO, Ojeremi TT, Olaleke DA, Ajidagba EB. Evaluation of food safety and sanitary practices among food vendors at car parks in Ile Ife, southwestern Nigeria. Food Control. 2014 Jun;40:165-71.

35. Nurudeen, AA, Lawal, AO, Ajayi, SA. A survey of hygiene and sanitary practices of street food vendors in the Central State of Northern Nigeria. J Public Health Epidemiol. 2014 May 19;6(5):174-81.

36. Gordon A, Swetman A, Albright K. Women in Post-Harvest Operations: Reducing the Drudgery [Internet]. Kent: Department for International Development; 2002. Available from: http://r4d.dfid.gov.uk/PDF/Outputs/CropPostHarvest/Issuepaper6.pdf

37. FAO. Developing gender-sensitive value chains: a guiding framework. Rome: Food and Agriculture Organization of the United Nations; 2016.

38. Palacios-López A, López R. The Gender Gap in Agricultural Productivity: The Role of Market Imperfections. The Journal of Development Studies. 2015 Sep 2;51(9):1175-92.

39. Croppenstedt AG Markus Rosas, Nina. Gender and Agriculture: Inefficiencies, Segregation, and Low Productivity Traps. World Bank Research Observer. 2013 Feb 1;28(1):79-109.

40. Peterman A, Behrman JR, Quisumbing AR. A Review of Empirical Evidence on Gender Differences in Nonland Agricultural Inputs, Technology, and Services in Developing Countries. Washington, DC: International Food Policy Research Institute (IFPRI); 2010. Report No.: FPRI Discussion Paper 00975.

41. Peters H, Irvin-Erickson Y, Adelstein S, Malik A, Derrick-Mils T, Valido A, et al. Qualitative evidence on barriers to and facilitators of women's participation in higher or growing productivity and male-dominated labour market sectors in low- and middle-income countries. London: EPPI Centre, Social Science Research Unit, UCL Institute of Education, University College London; 2019.

42. World Bank. Gender and governance in rural services: Insights from India, Ghana and Ethiopia. Washington, DC: World Bank; 2010.

43. Doss CR. Designing Agricultural Technology for African Women Farmers: Lessons from 25 Years of Experience. World Development. 2001 Dec 1;29(12):2075-92. 
44. FAO. Gender and food loss in sustainable food value chains - A guiding note. Rome: Food and Agriculture Organization of the United Nations; 2018.

45. SDC. Gender Analysis of Maize Post-Harvest Management in Malawi: A Case Study of Lilongwe and Mchinji districts. Bern: Swiss Agency for Development Cooperation (SDC); 2015 Mar.

46. Theis S, Lefore N, Meinzen-Dick R, Bryan E. What Happens after Technology Adoption? Gendered Aspects of Small-Scale Irrigation Technologies in Ethiopia, Ghana, and Tanzania. Washington, DC: International Food Policy Research Institute (IFPRI); 2017 Aug. Report No.: IFPRI Discussion Paper 01672.

47. Alderman H, Hoddinott J, Haddad L, Udry C. Gender differentials in farm productivity: implications for household efficiency and agricultural policy. Washington, DC: International Food Policy Research Institute (IFPRI); 1995. Report No.: Food Consumption and Nutrition Division Discussion Paper \#6.

48. Hoddinott J, Haddad L. Does Female Income Share Influence Household Expenditures? Evidence from Cote d'Ivoire. Oxford Bulletin of Economics and Statistics. 1995 Feb;57(1):77-96.

49. FAO. The state of food and agriculture: Women in agriculture. Closing the gender gap for development. Rome: Food and Agriculture Organization of the United Nations; 2011.

50. Abdulsalam-Saghir PB, Bennett B, Quaye W, Phu Tu V, Sanni LO, Martin AM. Gender analysis of households' decision-making to reduce post-harvest losses of cassava in Ghana, Nigeria, and Vietnam. Food Chain. 2015 Jun;5(1-2):53-70.

51. Sawadogo-Ouedraogo H. Gender dimension in the postharvest loss analysis and recommended solutions in Burkina Faso: sorghum, maize and cowpea. In Nairobi; 2017.

52. Cole SM, McDougall C, Kaminski AM, Kefi AS, Chilala A, Chisule G. Postharvest fish losses and unequal gender relations: drivers of the social-ecological trap in the Barotse Floodplain fishery, Zambia. E\&S. 2018;23(2):art18.

53. Kaminski AM, Cole SM, Al Haddad RE, Kefi AS, Chilala AD, Chisule G, et al. Fish Losses for Whom? A Gendered Assessment of Post-Harvest Losses in the Barotse Floodplain Fishery, Zambia. Sustainability. 2020;12(23).

54. Quisumbing A, Rubin D, Manfre C, Waithanji E, van den Bold M, Olney DK, et al. Closing the Gender Asset Gap: Learning from Value Chain Development in Africa and Asia. Washington, DC: International Food Policy Research Institute (IFPRI); 2014. (IFPRI Discussion Paper). Report No.: 01321.

55. Muravyev A, Talavera $O$, Schäfer D. Entrepreneurs' gender and financial constraints: Evidence from international data. Journal of Comparative Economics. 2009 Jun $1 ; 37(2): 270-86$.

56. Nordhagen S. Supporting Gender Equity through Food System Businesses in LowerIncome Countries. Geneva, Switzerland: Global Alliance for Improved Nutrition (GAIN); 2020. Report No.: GAIN Working Paper 11.

57. Nordhagen S, Condés S. Supporting Gender Equitable Food Systems through Access to Business Finance. Geneva, Switzerland: Global Alliance for Improved Nutrition (GAIN); 2020. Report No.: GAIN Working Paper 13. 
58. SDC. Gender Analysis of Maize Post-Harvest Management in Zambia: A Case Study of Chipata and Katete Districts. Bern: Swiss Agency for Development and Cooperation (SDC); 2015 Mar.

59. SDC. Gender Analysis of Maize Post-Harvest Management in Kenya: A Case Study of Nakuru, Naivasha and Embu Districts. Bern: Swiss Agency for Development Cooperation (SDC); 2015 Mar.

60. Nyanga LK, Chahwanda S, Ngaru M, Dembedza MP, Manema L, Ambali CP, et al. Transforming gender relations through the use of hermetic technology. International Development Research Centre;

61. Kaminski J, Christiaensen L. Post-harvest loss in sub-Saharan Africa-what do farmers say? Global Food Security. 2014 Nov;3(3-4):149-58.

62. Ruel MT, Quisumbing AR, Balagamwala M. Nutrition-sensitive agriculture: What have we learned so far? Global Food Security. 2018 Jun;17:128-53.

63. Harriss-White B. Commercialisation, Commodification and Gender Relations in PostHarvest Systems for Rice in South Asia. Economic and Political Weekly. 2005;40(25):253042.

64. IFPRI. 2020 Global Food Policy Report: Building Inclusive Food Systems [Internet]. 0 ed. Washington, DC: International Food Policy Research Institute; 2020 [cited 2021 Jan 23]. Available from: https://ebrary.ifpri.org/digital/collection/p15738coll2/id/133646

65. Carletto C, Corral P, Guelfi A. Agricultural commercialization and nutrition revisited: Empirical evidence from three African countries. Food Policy. 2017 Feb;67:106-18.

66. Cunningham K, Ploubidis GB, Menon P, Ruel M, Kadiyala S, Uauy R, et al. Women's empowerment in agriculture and child nutritional status in rural Nepal. Public Health Nutr. 2015 Dec;18(17):3134-45.

67. Jones AD, Cruz Agudo Y, Galway L, Bentley J, Pinstrup-Andersen P. Heavy agricultural workloads and low crop diversity are strong barriers to improving child feeding practices in the Bolivian Andes. Social Science \& Medicine. 2012;75:1673-84.

68. Kumar N, Nguyen PH, Harris J, Harvey D, Rawat R, Ruel MT. What it takes: evidence from a nutrition- and gender-sensitive agriculture intervention in rural Zambia. Journal of Development Effectiveness. 2018;10(3):341-72.

69. Shively GE, Sununtnasuk C. Agricultural diversity and child stunting in Nepal. Journal of Development Studies. 2015;51:1078-96.

70. Komatsu M, Malapit A, Thies S. How does women's time in reproduction work and agriculture affect maternal and child nutrition? Evidence from Bangladesh, Cambodia, Ghana, Mozambique, and Nepal. Washington, DC: IFPRI; 2015. (IFPRI Discussion Paper 1486).

71. Orr A, Tsusaka T, Kee-Tui SH, Msere H. What Do We Mean by 'Women's Crops'? Commercialisation, Gender and the Power to Name: Women's Crops. J Int Dev. 2016 Aug;28(6):919-37.

72. Zewde \& Associates. Jobs, Gender and Small Enterprises in Africa: Women Entrepreneurs in Ethiopia. A Preliminary Report. Geneva: International Labour Organization; 2002. 
73. Hosking S, Amin M, Zena Z, Yalch T, Nordhagen S. Business Models for Reducing PostHarvest Loss of Fresh Vegetables: An Assessment of Reusable Plastic Crates in Ethiopia [Internet]. Geneva: Global Alliance for Improved Nutrition (GAIN); 2021. Report No.: Working Paper \#17. Available from: https://doi.org/10.36072/wp.17

74. Cole SM, Kaminski AM, McDougall C, Kefi AS, Marinda PA, Maliko M, et al. Gender accommodative versus transformative approaches: a comparative assessment within a post-harvest fish loss reduction intervention. Gender, Technology and Development. 2020 Jan 2;24(1):48-65.

75. Ali D, Bowen, D, Deininger K, Duponchel M. Investigating the Gender Gap in Agricultural Productivity: Evidence from Uganda [Internet]. The World Bank; 2015 [cited 2019 Jun 13]. 32 p. (Policy Research Working Papers). Available from: https://doi.org/10.1596/18139450-7262

76. Coles C, Mitchell J. Gender and agricultural value chains: A review of current knowledge and practice and their policy implications [Internet]. Food and Agriculture Organization of the United Nations, Agricultural Development Economics Division (ESA); 2011. Available from: https://ideas.repec.org/p/ags/faoaes/289016.html

77. Ahmed, Akhter U., Malapit, Hazel J., Pereira, Audrey, Quisumbing, Agnes R., Rubin, Deborah, Ghostlaw, Julie, et al. Tracking empowerment along the value chain: Testing a modified WEAl in the Feed the Future Zone of Influence in Bangladesh. Washington, DC: International Food Policy Research Institute (IFPRI); 2018.

78. Johnson N, Balagamwala M, Pinkstaff C, Theis S, Meinzen-Dick R, Quisumbing A. How do agricultural development projects empower women? Linking strategies with expected outcomes. Journal of Gender, Agriculture and Food Security. 2018;3(2).

79. CAWTAR. Women Entrepreneurs in the Middle East and North Africa: Characteristics, Contributions and Challenges. Tunis: Center of Arab Women for Training and Research (CAWTAR) and International Finance Corporation's Gender Entrepreneurship Markets (IFC GEM); 2007. 